\title{
Prevalence of Dengue Virus Transovarial Transmission and DHF Incidence Rate in Grogol Sub-district of Sukoharjo District
}

\author{
Paul Sunardi*, Hari Kusnanto**, Tri Baskoro T. Satoto***, Lutfan Lazuardi** \\ * Correspondent Author: paul_sunardi@yahoo.co.id \\ * Student in Doctoral Program, Faculty of Medicine, Universitas Gadjah Mada, Yogyakarta, Indonesia \\ **Department of Public Health, Faculty of Medicine, Universitas Gadjah Mada, Yogyakarta, Indonesia \\ ***Department of Parasitology, Faculty of Medicine, Universitas Gadjah Mada, Yogyakarta, indonesia
}

I N D E X I N G

Keywords:

DHF;

virDEN-3;

Transmission;

Mosquitoes;

Virus;

\section{Kata Kunci:}

DHF;

Virden-3;

Transmission,

Mosquitoes;

Virus;

\begin{abstract}
A B S T R A C T
Environmental changes in physical, biological, and social aspects have enabled the occurrence of DHF cases in Sukoharjo. Such changes may affect virulence of dengue virus, shorten extrinsic periods and increase vector dengue capacity. This study aimed to determine the spread of dengue virus transovarial transmission and the incidence rate of DHF in Grogol Sub-district of Sukoharjo District. This observational analytic study used a cross-sectional approach conducted in 2016. The population was Ae. aegypti mosquitoes and DHF patients (based on laboratory diagnosis with serologic examination, i.e., IgG, IgM and/or NS1 indicating positive DHF). Data analysis used Chisquare, Multiple Linear Regression, and spatially weighted regression with GeoDa and SatScan. The study found virDEN-3 transovarial transmission in Grogol Sub-district of Sukoharjo District and the spread of virDEN-3 transovarial transmission following the high spread of Ovitrap Index. The DHF incidences (cases) tended to cluster at a radius of $100-200 \mathrm{~m}$ from a region found the positive virDEN-3 transovarial transmission. The statistical tests showed a relationship between the virDEN-3 transovarial transmission and the DHF incidence with a p-value of $<0.05$. Spatially, the incidence of DHF in this area followed a certain spatial distribution pattern, with a clustering of dengue cases centered on the coordinates of $-7.588240 \mathrm{~S}, 110.809450 \mathrm{E}$ with a radius of $2.00 \mathrm{~km}$.
\end{abstract}

\begin{abstract}
Berdasarkan peningkatan kasus DBD di Sukoharjo, dimungkinkan telah terjadi perubahan lingkungan baik fisik, biologi, dan sosial. Perubahan tersebut dapat mempengaruhi virulensi virus dengue, memperpendek periode ekstrinsik serta meningkatkan kapasitas vektor DBD. Tujuan penelitian ini adalah mengetahui penyebaran prevalensi transmisi transovarial dan tingkat kejadian demam berdarah dengue (DBD) di Kecamatan Grogol Kabuapten Sukoharjo. Jenis penelitian adalah observasional analitik dengan pendekatan Crossectional. Penelitian dilaksanakan dengan rancangan studi potong lintang (cross-sectional) Penelitian ini dilaksanakan di Kecamatan Grogol Kabupaten Sukoharjo pada tahun 2016. Populasi penelitian adalah nyamuk Ae.aegypti dan pasien DBD (didiagnosis laboratorium dengan pemeriksaan serologi yaitu IgG, IgM dan atau NS1 menunjukkan positif DBD). Analisis data menggunakan Chi-square, Regresi Linier Berganda dan spatially weighted regression menggunakan GeoDa dan SatScan. Hasil penelitian menunjukkan ada transmisi transovarial virDEN-3 di Kecamatan Grogol Kabupaten Sukoharjo, penyebaran transmisi transovarial virDEN-3 di Kecamatan Grogol Kabupaten Sukoharjo mengikuti persebaran Ovitrap Index yang tinggi. Kecendrungan timbulnya kejadian DBD (kasus) di Kecamatan Grogol Kabupaten Sukoharjo terjadi mengelompok pada radius 100-200 m dari wilayah yang ditemukan positif terjadi transmisi transovarial virDEN-3. Ada hubungan transmisi transovarial virDEN-3 dengan kejadian $D B D$ di Kecamatan Grogol Kabupaten Sukoharjo $(p<0,05)$. Secara spasial kejadian DBD di Kecamatan Grogol mengikuti pola distribusi spasial tertentu $(p<0,05)$. Ada clustering kasus DBD di Kecamatan Grogol Kabupaten Sukoharjo, berpusat pada koordinat -7.588240 S, 110.809450 E dengan radius $2,00 \mathrm{~km}$.
\end{abstract}

(C) 2018JMMR. All rights reserved

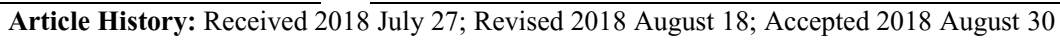

\section{INTRODUCTION}

Dengue hemorrhagic fever (DHF), an infectious disease transmitted from one person to another, is caused by dengue virus carried by the Aedes (Ae.) mosquito of the subgenus Stegomyia. From the subgenus, Ae. aegypti is the most important epidemic vector, while Ae. albopictus is the secondary one. The dengue virus belongs to the genus 
Flavivirus of the family Flaviviridae, and is a single stranded RNA nucleotide virus. Based on its serotype, the dengue virus is divided into DEN-1, DEN-2, DEN-3 and DEN-4. ${ }^{1}$ The dengue virus results in varying clinical manifestations from flu or Dengue Fever (DF), Dengue Hemorrhagic Fever (DHF), to Dengue Shock Syndrome (DSS), which is sometimes accompanied by convulsions due to encephalopathy. ${ }^{2,3}$

The increasing number of dengue fever cases and the widespread of areas reporting the incidence of the cases in Indonesia are due to very complex and varied factors. DHF is a disease closely related to the environment; thus, changes in one or several environments can lead to changes in the life cycle of mosquitoes, which will ultimately affect the incidence of DHF in the region. In this last period, the growing phenomenon due to the evidence of transovarial transmission can put more health concerns in Indonesia. Halstead in 1990 did actually review the vertical transmission mechanism but the proof of transovarial transmission in Indonesia was conducted by Mardihusodo (2007) and Tribuwono et al (2006), ${ }^{4,5}$ with the later showing transovarial transmission proven in Semarang of Central Java.

Initial surveys conducted on 4-14 April 2015 in Langenharjo and Telukan villages, Grogol sub-district, Sukoharjo District, done with epidemiological inquiry, show some important preliminary data, i.e., slum settlements, various factory buildings, numerous counters supporting mosquito larvae, dense population, and lack of awareness of the importance of environmental hygiene. Data on the number of DHF cases per sub-district at Grogol Public Health Center in 2012 showed 36 cases and no casualties. In 2013, the number of cases increased to 233 cases with IR by $0.20 \%$ and CFR mortality by $0.002 \%$. For 2014, the number of cases decreased to 152 cases but the number of people who died became four, with IR by $0.13 \%$ and CFR by $2.6 \%$. To date, efforts have been made to prevent the increase and spread of the disease through prevention programs.

Based on the aforementioned data, environmental changes in terms of physical, biological, and social had possibly occurred. Environmental changes that occur in Sukoharjo District are, among others, the increase in air temperature, humidity, rainfall, reduced vegetation due to the use of agricultural land/plantations for settlements, and increasing population density and population mobility. Such changes may affect virulence of dengue virus, shorten extrinsic periods, and increase the capacity of dengue vectors.

\section{RESEARCH METHOD}

This analytic observational study used a crosssectional study design conducted in Grogol Sub-district of Sukoharjo District in 2016 and at the Parasitology Laboratory of the Faculty of Medicine of Universitas Gadjah Mada (FM-UGM) of Yogyakarta. The population of the study was Ae.aegypti mosquito of egg origin, the result of colonization at the Parasitology Laboratory of FMUGM, while the area population was the entire villages in the Grogol Sub-district and all the dengue fever cases (laboratory diagnosis with serology, i.e., IgM and/or DHF NS1 positive). The sample of the study was the Ae.aegypti mosquito from the eggs as the result of colonization at the Parasitology Laboratory of FM-UGM, taken from each village in DHF epidemic and sporadic areas and all cases of DHF (DHF positive laboratory diagnosis result with serologic examination, i.e., IgG , IgM, and/or NS1). This research has been approved by the Research Ethics Committee of FM-UGM.

The collection of Ae.aegypti mosquito eggs used an ovitrap labeled according to location outside/inside the house. ${ }^{6,7}$ The colonization of mosquitoes at the Parasitology Laboratory of FM-UGM from egg to adult was done to obtain adult mosquitoes which were then processed for virDen detection. ${ }^{8}$ RT PCR was employed for dengue virus examination. ${ }^{9,10}$ Spatial mapping of dengue hemorrhagic cases found during the study used a GPS device and the data were then analyzed with GIS software (SaTScan, GeoDa and Arc GIS) based on field surveys such as vector breeding sites and environmental factors. Furthermore, the breeding sites were made buffer ${ }^{11}$ in each area representing the mosquito sources. Buffer zone is useful to assess the level of vulnerability of the emergence of mosquitoes to infect humans.

The results of descriptive analysis were presented in the form of a narrated table. Bivariate analysis was done by chi-square test to determine whether there was a correlation between an independent variable, i.e., prevalence of DEN3 transovarial transmission and a dependent variable, i.e., DHF incidence. Spatially weighted regression analysis was done by using GeoDa to determine whether there was an influence between an independent variable, i.e., DEN3 transovarial transmission prevalence and a dependent variable, i.e., DHF incidence. Lastly, multivariate analysis was done using multiple linear regression test to determine whether there was an influence between the climatology indicators (temperature, humidity and rainfall) and the incidence rate. 


\section{RESULT AND DISCUSSION}

Based on the results of the electrophoresis of RT PCR Serotyping Dengue examination from 12 samples, there were seven DEN-3 virus positive samples, i.e., the
Village of Pondok, Sanggrahan, Cemani, Grogol, Telukan, Langenharjo, and Gedangan. Grogol Sub-district is the most endemic area of DHF in Sukoharjo District. The number of DHF cases per village in Grogol Sub-District can be seen in Table 1 .

Table 1. The number of DHF cases in Grogol Sub-district of Sukoharjo District

\begin{tabular}{llcccc}
\hline \multirow{2}{*}{ No } & & \multicolumn{2}{c}{$\mathbf{2 0 1 5}$} & \multicolumn{2}{c}{ Per July 2016 } \\
\cline { 3 - 6 } & & Number & $\mathbf{\%}$ & Number & \% \\
\hline 1 & Langenharjo & 20 & 13.2 & 7 & 9.3 \\
2 & Parangjoro & 6 & 3.9 & 3 & 4.0 \\
3 & Pandeyan & 6 & 3.9 & 3 & 4.0 \\
4 & Kadokan & 5 & 3.3 & 2 & 2.7 \\
5 & Pondok & 4 & 2.6 & 4 & 5.3 \\
6 & Grogol & 16 & 10.5 & 9 & 12.0 \\
7 & Madegondo & 10 & 6.6 & 6 & 10.7 \\
8 & Telukan & 24 & 15.8 & 7 & 9.3 \\
9 & Kwarasan & 7 & 4.6 & 7 & 9.3 \\
10 & Gedangan & 6 & 3.9 & 0 & 0.0 \\
11 & Manang & 3 & 2.0 & 7 & 9.3 \\
12 & Sanggrahan & 14 & 9.2 & 0 & 0.0 \\
13 & Banaran & 5 & 3.3 & 12 & 16.0 \\
14 & Cemani & 26 & 17.1 & $\mathbf{7 5}$ & $\mathbf{1 0 0}$ \\
\hline
\end{tabular}

The nearest neighbor analysis (NNA) in this study was to find out whether the spreading pattern of DHF was uniform, random or clustered. This analysis used data of distance between one case coordinate point and another. The pattern consisted of 3 categories, i.e., cluster if the value is less than 0 , random if the value is 1 , and uniform if the value is $2.5 .^{12}$

Buffer for the range of virDEN3 transovarial transmission against the incidence of DHF was done to see whether there was any clustering of cases around the positive region of virDEN3 transovarial transmission. Figure 8 shows case groupings on the buffer of virDEN3 transovarial transmission. Nearest neighbor analysis (NNA) toward the $100 \mathrm{~m}$ buffer found a tendency of clustering cases at a radius of $100-200 \mathrm{~m}$.

Based on Figure 1, in Grogol Sub-district there were seven villages that were positive virDEN3transovarial transmission. In addition, based on the buffer analysis, at a radius of 200 meters from virDEN3 transovarial transmission, 32 cases were found. However, with the same radius and buffer analysis, 5 villages with negative virDEN3 transovarial transmission showed only 6 cases found.

From the 200 meter buffer analysis, the number of cases in the areas (villages) with positive DEN3 transovarial transmission had a higher percentage than those with negative one. In the positive areas, there were four cases in Pondok Village $(100 \%)$, six cases in Gedangan (100\%), eight cases in Sanggrahan (100\%), ten cases in Cemani (83.33\%), six cases in Telukan (75\%), six cases in Grogol (66.67\%), and three cases in Langenharjo $(42.86 \%)$. For the areas with negative transmission, two cases were found in Parangjoro (66.7\%), two cases were in Pandeyan (66.7\%), one case was in Kadokan (50\%), and six cases were in Kwarasan (85.7\%)

The chi-square test showed an X2 value of 6.395 with a p-value of 0.011 ; thus, there was a significant correlation between DEN-3 transovarial transmission and DHF incidence. In other words, the higher the proportion of DEN-3 transovarial transmission, the more DHF incidences in Grogol Sub-district of Sukoharjo District. The Odd Ratio (OR) calculation showed an OR value of 2.219; thus, the areas with positive DEN-3 transovarial transmission had a 2.219 time greater risk of contracting DHF than those with negative transmission.

Spatially weighted regression (spatial error model) analysis with GeoDa was

intended to find out the suitability of Transovrial 
Transmission Map (result of RT PCR electrophoresis of Serotyping Dengue 3) with the incidence of DHF in Grogol District where the two items of mapping were stacked. The result of analysis showed a $\mathrm{z}$ value of 5.606017 and a $\mathrm{p}$ of $0.000(\mathrm{p}<0.05)$; thus, there was a significant relationship between transovrial transmission and DHF incidence in Grogol District. It could also be said that the incidence rate of DHF was related to virDen 3 transovrial transmissions.

The Likelihood Ratio Test showed the $\mathrm{p}$ value of $0.0027306(\mathrm{p}<0.05)$; thus, the occurrence of DHF followed a certain spatial spread pattern. In other words, the incidence of DHF was influenced by the factors in the area/spatial distribution where the dengue patients lived. Further analysis used Poisson Model, Purely Spatial based on village unit analysis (aggregate data) and the use of population variable. The result showed one cluster as the Most Likely Cluster which happened from 1 January 2016 to 31 December 2016 centered on coordinate of -7.588240 $\mathrm{S}, 110.809450 \mathrm{E}$ at a radius of $2.00 \mathrm{~km}$, i.e., in RW 21 of Cemani Village adjacent to RW 6 of Sanggrahan Village.

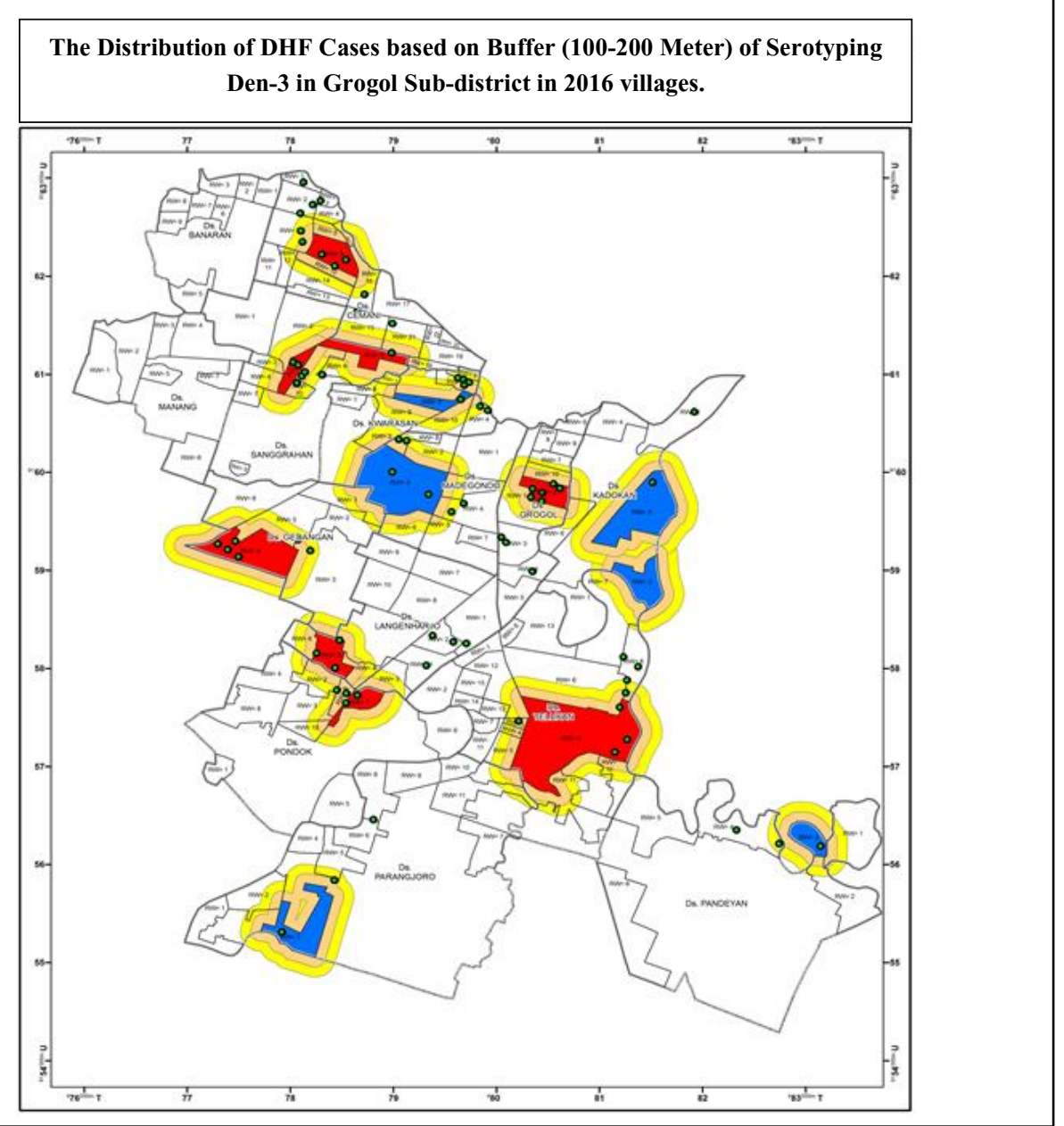

Figure 1. The Distribution of DHF Cases based on Buffer (100-200 Meter) of Serotyping Den-3 in Grogol Sub-district in 2016

\section{Discussion}

This study proves the existence of transovarial transmission in a number of dengue endemic villages. The transovarial examination shows the vertical transmission occurred from female mosquitoes to their eggs. Transovarial transmission causes an area to continue to be endemic because cases will always exist and not be interrupted. DHF persistently transmitted transovarially will increase in frequency until the seventh generation. ${ }^{13}$ This condition might be caused by decreased rainfall in 2016, 
while in 2015 rain frequently fell throughout the year. Climatic factors affect the number of dengue cases, i.e., the temperature and relative humidity during the rainy season supporting the propagation of dengue virus. ${ }^{14}$ Another study conducted in Malaysia to prove the virDen transovarial transmission in its role for epidemiology Dengue concluded that virDen transovarial transmission in Ae. aegypti plays a role in improving and maintaining Dengue epidemic, while the presence of virDen transovarial transmission in $\mathrm{Ae}$. albopictus provides clues to the presence of dengue cases within the period of 7-41 days. ${ }^{15}$

This study shows that there is a significant relationship between transovarial transmission and DHF incidence in Grogol Sub-District of Sukoharjo District ( $\mathrm{p}=$ $0.000, \mathrm{p}<0.05$ ). In other words, the incidence of DHF is related to virDEN-3 transovrial transmission. The presence of dengue virus transovarial infection in Aedes aegypti mosquitoes shows that mosquitoes play an important role as viral transmitters and as a defense for the dengue epidemic. ${ }^{15}$ This is the cause dengue endemic to occur in the area and DHF cases always increase in the rainy season. The dengue virus (virDEN-3) in the mosquito's body can be transmitted at any time. Spatial analysis using Geoda shows that spatially the occurrence of DHF in Grogol Subdistrict follows certain a spatial spread pattern, meaning the DHF incidence is influenced by factors that exist in the area/ space with the distribution of dengue cases. Grogol Sub-district has a temperature and humidity level of $70 \%$ which is ideal for viruses both in eggs and in mosquito bodies.

Eggs obtained from Ae.aegypti mosquitoes in intravenous (parenteral) DEN-3 viral infections when it is incubated at several weeks of the incubation period at room temperature, the percentage of transovarial transmission increases. This suggests that at room temperature, the virus has the opportunity to multiply during embryonic time in the egg. ${ }^{13}$ This study also shows that during the dry season when mosquitoes get a chance to suck the blood of viraemia host and lay their eggs in an appropriate environment, some eggs can live through inter-epidemic periods of life, and initiate the viral life cycle of humanmosquito-human. Transovarial transmission can last up to the $7^{\text {th }}$ generation of mosquitoes with virDEN parenteral infection. Transovarial transmission is assumed to be an important aspect in maintaining virDEN during interepidemic in environment. ${ }^{13}$

\section{CONCLUSION}

In this study, virDEN-3 transovarial transmission is correlated to DHF incidence, in which spatially the incidence follows a certain spatial spread pattern. The factors playing a role in virDen transmission or dengue cases distribution include temperature, humidity, and rainfall ideally.

\section{REFERENCE}

1. WHO. 2004. Situation Of Dengue/Dengue Haemorrhagic Fever In the South-East Asia Region: Prevention And Control Status In SEA Countries [Internet]. Terdapat dalam: $<$ http://w3.whosea.org/en/Section10/Section332.htm> [Retrieved August 27, 2014].

2. Henchal, E. A dan Putnak, J.R. 1990. The Dengue viruses. Clin Microbiol Rev : 3 (4) : 376-396.

3. Bai, L., Xia, S., Lan, R., Liu, L., Ye, C., Wang, Y., et $\mathrm{al}, 2013$. Isolation and Characterization of cytotoxic Aggregative Citrobacter freundii. (N. Ahmed, Ed.) Plos One, 7(3), 1-2.

4. Mardihusodo, S.J., Satoto, T.B.T., Mulyaningsih, B., Umniyati, S.R. \& Ernaningsih. 2007. Evidence of Transmission of Transmissal Dengue Virus In Aedes aegypti Mosquito In Yogyakarta City. National Symposium on Molecular Biology Aspect, Pathogenesis, Management and Prevention of Outbreak, Center for Biotechnology Studies UGM, Yogyakarta, 16 May 2007.

5. Tri Boewono, Widiarti, Umi Widyastuti, Mujiono \& Lasmiati, 2006. Detection of Dengue virus in the parent and progeny of Aedes aegypti dengue vector in some endemic areas in Central Java. In one day seminar vector control and disease reservoir strategy on emergency disaster emergency in the era of decentralization, Salatiga 20 September 2006.

6. Perich, M.J, Kardec. A, Braga, I.A., Portal, L.F., Burge, R, Zeichner, B.C, Brogdon, W.A., Wirtz, R.A., 2003. Field Evaluation of a Lethal Ovitrap Against DenguenVector in Brazil, Medical Veterinary Entomology, Brazil, 205-209, www.blackwellsynergy.com, Download 05 Maret 2007.

7. Hasyimi, M., Eny W. Lestari, Supratman, S. 1992. Pleasure Spawning Aedes sp, Center for Health Ecology Research, Research and Development Agency of Health MOH RI, Jakarta, delivered to Congress Entomologi IV, in Yogyakarta. 
8. Mardihusodo S.J. 1993. Aedes aegypti Resistance Early Detection Research Report on Malathion and Temephos. Research Institute of Gadjah Mada University, Yogyakarta.

9. Sudjadi, 2008. Health Biotechnology. Kanisius Publisher. Yogyakarta. Hal: 94-99 and stuff: 131-143

10. Harris,E. T.G.Robert. L.Smith. J.Selle.et al. 1998. Typing of Dengue Viruses in Clinical Specimens and Mosquitoes by Single-Tube Multiplex Reverse Transcriptase PCR, Journal of Clinical Microbiology, Sept.1998,p.2634- 2639

11. Charoenpanyanet, A and Chen, X. 2008. SatelliteBased Modeling of Anopheles Mosquito Densities on Heterogeneous Land Cover in Western Thailand. The International Archives of the Photogrammetry, Remote Sensing and Spatial Information Sciences.
Vol. XXXVII. Part B8. Beijing.

12. Diggle, P., 2003. Statistical Analysis of Spatial Point Patterns, 2nd ed. Arnold, London, UK.

13. Joshi V, Mourya DT, Sharma RC, 2002. Persistence of Dengue-3 Virus Through Transovarial Transmission Passage In Successive Generations of Aedes aegypti Mosquitoes. Am.J.Trop.Med.Hyg.,67 :158 -161.

14. Thu,H.M., K. Lowry,T.T.Myint,et al. 2004. Myanmar Dengue Outbreak Associated with Displacement of Serotype 2,3, and 4 by Dengue 1 . Emerg. Infection. 10:593-597

15. Lee, H.L. \& Rohani, A. 2005. Transovarial Transmission Of Dengue Virus In Aedes aegypti And Aedes albopictus In Relation to Dengue Outbreak In An Urban Area In Malaysia. Dengue Bulletin. 29 : 106-111. 